\title{
THE RISE OF PRIVATE PROPERTY RIGHTS IN THE BROADCAST SPECTRUM
}

\author{
KRYSTILYN CORBETT
}

\section{INTRODUCTION}

The Telecommunications Act of $1996^{1}$ implemented two competing views of broadcasters' roles and their rights to use the airwaves. ${ }^{2}$ Section 201 of the Act treats broadcasters as holders of rights that can be exchanged with the Federal Communications Commission (FCC) in a market-like transaction: ${ }^{3}$ if the FCC issues additional licenses for advanced television broadcast services, ${ }^{4}$ the statute requires the FCC to limit initial ehgibility to broadcasters who possess a current license. ${ }^{5}$ In exchange, those broadcasters surrender their original licenses. ${ }^{6}$ Section 204 significantly increases current license terms. ${ }^{7}$ By prohibiting the FCC from considering coinpetitors for a license at renewal and by extending license terms, the Act appears to guarantee an unprecedented longevity for broadcasters' current rights to use the airwaves and to transforn a teinporary and conditional broadcast license into one of virtually permanent duration.

Interestingly, these provisions coexist witl other provisions of the Act that treat broadcasters as public trustees. Under the Act's "public trustee" provisions, broadcasters' rights to use the airwaves

1. Pub. L. No. 104-104, 110 Stat. 56 (1996) (to be codified at scattered sections of 47 U.S.C.).

2. Generally, "airwaves" refers to those portions of the electromagnetic spectrum used in broadcast communications, cellular phones, airport radar, satellites, and garage door openers. See Frank James, Politicians See Airwave Sales as Easy Money, CHI. TRIB., Sept. 1, 1996, at C3. This Note focuses on the use of airwaves for broadcast communication, i.e. radio and television.

3. § 201,110 Stat. at 107 (amending 47 U.S.C. by adding $\S 336$ ).

4. Advanced television uses digital signals, which produce a sharper, cleaner picture than does conventional, analog television. See Jeannine Aversa, Digital TV Nearer After FCC Decree, AUSTIN AMERICAN-STATESMAN, July 26, 1996, at A19.

5. See $\$ 201$ (a), 110 Stat. at 107.

6. See $\$ 201$ (c), 110 Stat. at 108 ("If the Commission grants a license for advanced television services ... the Commission shall, as a condition of such license, require that either the additional license or the original license . . . be surrendered to the Commission for reallocation or reassignment.").

7. See § 204(a)(4), 110 Stat. at 113 (amending 47 U.S.C. $\S 309$ ). 
are allocated and attach not on the basis of what the broadcasters "own" and can exchange, but rather on the basis of "public interest, convenience, and necessity."

This tension-between a vision of broadcasters as market participants, with whonı government must bargain to exchange resources, and a vision of broadcasters as public trustees who use the airwaves for public benefit-is apparent in public debate as well as in legislation. ${ }^{9}$ The claim that the airwaves belong to the public is at the base of calls for access to broadcast facilities, ${ }^{10}$ improved children's programming, ${ }^{11}$ and auctions of the airwaves. ${ }^{12}$ But despite these appeals to the concept of public ownership, public debate also presents broadcasters as market participants. ${ }^{13}$ The responsibilities of public trustees and inarket participants differ, however: these two visions are often inconsistent.

8. § 201(d), 110 Stat. at 108.

9. See Aversa, supra note 4 , at A19. One commentator has criticized broadcasters for thinking "they own the ether," and for dismissing "the concept of what used to be called the 'public airwaves."' Joanne Ostrow, Media Monsters Keep Getting Bigger, More Powerful, DENVER POST, June 26, 1996, at G1.

10. For example, Pat Choate, the Reform Party's candidate for Vice-President, has argued that one reason he should not have been excluded from the 1996 Vice-Presidential debates is that the debates were to be broadcast on "the public's airwaves." Interview with Pat Choate, Vice-Presidential Candidate, Reform Party (Morning Edition, National Public Radio broadcast, Sept. 20, 1996) (transcript on file with author).

11. Reed Hundt, the current FCC Chairman, has emphasized the concept of public ownership of the airwaves when encouraging broadcasters to provide more educational and children's programming. See Reed E. Hundt, The Public's Airwaves: What Does the Public Interest Require of Television Broadcasters? 45 DuKE L.J. 1089, 1095 (1996). Another commentator takes for granted that broadcasters own a slice of the airwaves, arguing that the federal government should simply "charge a fee for [the airwaves]," and then use the money raised to create a trust fund for children's programming. Eric Mink, Kid Content: Election Static, N.Y. DAILY NEWs, June 4, 1996, at 67.

12. As Senate Majority Leader, Bob Dole used the concept of public ownership of the airwaves to argue that rights to airwaves newly set aside for advanced television should be given in exchange for auction-generated revenue, rather than in exchange for existing licenses. See Waldo Proffitt, Dole vs. Communications Giants, SARASOTA HERALD-TriB., Aug. 14, 1996, at 11A.

13. For a critique that recognizes that the "public ownership" concept may ignore the substance of regulation, see James, supra note 2, at C3. James argues that if the airwaves are a public resource, then they should not be sold at all. "[O]nce you sell it, it's never back im public hands." Id. Another commentator, however, sees the dual roles of a broadcaster as complementary. See Shepard Nevel, Seeking Unfiltered Information, DENVER POST, June 30, 1996, at D1 ("As profit-oriented businesses they can garner ... good will. ... And as custodians of the public airwaves, they can improve the quality of political discussion.”). 
The debate about broadcasters' use of the "public's airwaves" is, at center, a debate about ownership of an essentially intangible resource, the electromagnetic spectrum. ${ }^{14}$ The concept of "ownership" of portions of this spectrum is central to broadcast regulation because it is central to the models on which broadcast regulation has been based. Broadcasters have been regulated under two different models: a public trust model and a private market model. ${ }^{15}$ The public trust model rests on public ownership of the electromagnetic spectrum. As owner, the public allocates to broadcasters limited rights to use the electromagnetic spectrum. In return, broadcast licensees subordinate their imterests to those of the public. ${ }^{16}$ In this model, broadcasters are essentially trustees of the public's airwaves; government is the guardian of the public's interests.

The private market model, in contrast, rests on broadcasters' status as owners of private property-that is, as owners of portions of the electromagnetic spectrum. Broadcasters are thus endowed with specific rights of ownership, including the right to control the property's use, to exclude use by others, and to exercise discretion in acquisition and transfer. ${ }^{17}$ Broadcasters also secure these rights

14. The electromagnetic spectrum is a range of "electromagnetic radiations that travel at the speed of light." Jora A. Minasian, Property Rights in Radiation: An Alternative Approach to Radio Frequency Allocation, 18 J.L. \& ECON. 221, 223 (1975). The energy within this range has different characteristics depending on its frequency (i.e., the number of waves that pass a fixed imaginary point in a second). See James, supra note 2, at 3. A broadcaster and a listener are able to communicate if the listener's receiver is tuned to the same frequency on which the broadcaster is sending its signal.

When sufficiently powerful, multiple signals are sent on the same (or nearly the same) frequencies in a similar geographical area, they interfere with one another. See HARVEY J. LEVIN, THE INVISIBLE RESOURCE 17 (1971). When this interference occurs, it results in a reduction of the quality of the desired signal. See id. The ability to prevent this interference is, in part, what it means to own a portion of the electromagnetic spectrum. See Minasian, supra, at 228 ("The right to emit energy is virtually worthless without a corresponding right to exclude.").

15. See Mark S. Fowler \& Daniel L. Brenner, A Marketplace Approach to Broadcast Regulation, 60 TEX. L. REv. 207, 209-13, 221-30 (1982) (arguing that a public trust paradigm has failed and should be replaced with a market-based approach).

16. See infra notes 53-101 and accompanying text (discussing the public trust model m broadcast regulation).

17. Theorists have different views of which characteristics inhere in a property right. Jora A. Minasian has compiled a thoughtful list in the context of the electromagnetic spectrum. See Minasian, supra note 14, at 232. The characteristics presented here are substantially the sanie; they differ only in that Professor Minasian separates "emission rights" and "admission rights," both of which I treat as part of the right to exclude. 
for some extended period of time. These private property rights are allocated through price, which is not responsive to a broadcaster's loyalty to the public interest. In this model, broadcasters owe no obligation to the public-they please the public only to profit from the use of the airwaves. ${ }^{18}$ They are simply players in a market; government's role is that of an arbiter among many private interests competing for the use of a valuable, scarce resource. $^{19}$

The history of broadcast regulation in the United States is a history of the conflict between these models, in which public ownership lias gradually given way to private ownership under the private market model. This Note describes this conceptual shift. Part I reviews the public trust nodel and describes its historical role im broadcast regulation, especially its effect on the regulation of broadcast content. Part II summarizes several principal criticisms of the public trust model, and argues that these criticisms have been influential in the shift to a private market model. Part III discusses the expansion of private property rights in the electromagnetic spectrum, noting the particular effect of: 1) a growing reliance interest $\mathrm{m}$ these rights, created by the relationship between broadcasters and the $\mathrm{FCC},{ }^{20}$ 2) a deregulation philosoplyy that has demanded that resources be allocated based on neutral,

The characteristics mentioned here also overlap with Antony Maurice Honorés six incidents of property, as restated by Professor Munzer. See STEPHEN R. MUNZER, A THEORY OF PROPERTY 22 (1990) (citing A.M. Honore, Ownership, in OXFORD ESSAYS IN JURISPRUDENCE (FIRST SERIES) 107-47 (A.G. Guest ed.) (1961)). Honore's six incidents are the following: 1) claim-rights to use, manage, and receive income, 2) powers to transfer, waive, exclude, and abandon, 3) liberties to consume or destroy, 4) immunity from expropriation, 5) duty not to use harmfully, 6) liability for execution to satisfy a court judgment. See id. Because the six incidents are joimtly sufficient, but not individually necessary, I have dropped the fifth and sixth incidents from the discussion; they are of limited usefulness when discussing the electromagnetic spectrum.

18. See infra notes $154-252$ and accompanying text (discussing the importance of private property rights to the private market model).

19. See Fowler \& Brenner, supra note 15, at 211; Richard W. Stevens, Anarchy in the Skip Zone: A Proposal for Market Allocation of High Frequency Spectrum, 41 FED. COMM. L.J. 43, 66 (1988) (comparing adninistrative control and adjustment of private interests).

20. A party's rehance on administrative regulation or rules can help to establish private property rights. See Ruckelshaus v. Monsanto Co., 467 U.S. 986, 987 (1984) (holding that an agency must recognize certain investment-backed expectations as property rights); see also Joseph William Singer, The Reliance Interest in Property, 40 STAN. L. REv. 611, 699 (1988) (arguing that property rights can arise from certain long-established relatiouships). 
market-based criteria; ${ }^{21}$ and 3) the United States Supreme Court's First Amendment jurisprudence, which has increased broadcasters' editorial discretion at the expense of public control.

\section{The Public Trust Model}

The common law doctrine of the public trust is based on common or public ownership. ${ }^{22}$ Under Enghish common law, common property was held by the sovereign in trust for the citizens. ${ }^{23}$ American common law adopted this same doctrine; ${ }^{24}$ courts held that land which had been held in trust by the Enghish sovereign (the Crown) vested in the American sovereign (the people) after the American Revolution. ${ }^{25}$ The public trust doctrine requires that certain property be used for public benefit, because of either its unique characteristics or its essentially public nature. It may mean that the owner of otherwise privately-owned property is required to provide public access; ${ }^{26}$ it may also preclude private ownership altogether. ${ }^{27}$ Together, public access and the impossibility of private ownership form the basis of administrative management of the electromagnetic broadcast spectrum. ${ }^{28}$

21. See Terrence J. Schroepfer, Fee-Based Incentives and Efficient Use of Spectrum, 44 FED. COMM. L.J. 411, 430 (1992) ("A private-enterprise system cannot function properly unless property rights are created in resources, and, when this is done, someone wishing to use a resource has to pay the owner to obtain it." (quoting R. H. Coase, The Federal Communications Commission, 2 J.L. \& ECON. 1, 14 (1959))).

22. See Shively v. Bowlby, 152 U.S. 1, 11-12 (1894); see also Matthews v. Bay Head Improv. Ass'n, 471 A.2d 355, 361 (N.J. 1984) (stating that property held in trust for the public is "common to all the citizens") (quoting Arnold v. Mundy, 6 N.J.L. 1, 93 (N.J. Sup. Ct. 1821)).

23. From English common law, the public trust doctrine can be traced back to Roman jurisprudence, in which "the law of nature" dictated that "the air, running water, the sea, and consequently the shores of the sea" were "common to mankind." Matthews, 471 A.2d at 360 (quoting JustinIAN, INSTrTUTES 2.1.1 (T. Sanders trans., 1st Am. ed. 1876)).

24. See Shively, 152 U.S. at 14.

25. See Mathews, 471 A.2d at 360-63.

26. See, e.g., id. at 365-69 (holding that the owner of land below the high tide mark must provide to the residual owners of a section of beach below the high tide mark-the public-riglits of access).

27. See Shively, 152 U.S. at 11 (hoiding that the lands below the high tide mark are "incapable of ordinary and private occupation"); see also Illinois Central R. R. Co. v. Illinois, 146 U.S. 387, 459-60 (1892) (holding that the public trust doctrine may restrain ability to alienate navigable waters and submerged lands forming harbors).

28. The Communications Act of 1934 incorporated both these tenets of the public trust doctrine. It specifically prohibited private ownership of the broadcast spectrum. See Communications Act of 1934, Pub. L. No. 73-416, § 301, 48 Stat. 1064, 1081 (providing 
The electromagnetic spectrum was not always considered a common or publicly-owned resource. The idea of public ownership is a product of history and politics as much as of the cliaracteristics of the electromagnetic spectrum itself..$^{29}$ After broadcast, or "wireless," communication was first developed, rights to use a particular frequency of the electromagnetic spectrum were allocated through a "first-in-time" principle, as were many private property rights under the common law. ${ }^{30}$ One who wanted to broadcast simply appropriated a suitable frequency; one who came later found another, unused frequency. Rights established through the first-in-time principle were not, lowever, recognized and enforced consistently, and so many conflicts arose. ${ }^{31}$ These conflicts were addressed not by applying or enforcing riglits created througli the previous first-in-time system. ${ }^{32}$ Instead, conflicts

for the "use of such channels, but not the ownership thereof"); id. $\& 309(b)(1), 48$ Stat. at 1085 (stating that a station license does not give the licensee any rights beyond the term of the license). In addition, the Act provided for public access to licensed portions of the electromagnetic spectrum. See id. $\S 315,48$ Stat. at 1088.

29. See Thomas W. Hazlett, The Rationality of U.S. Regulation of the Broadcast Spectrum, 33 J.L. \& ECON. 133 (1990), 139-147 (setting forth the "conventional" view of the history of broadcast regulation, and then offering a different view, holding that the drafters of the Radio Act of 1927 and the Commumications Act of 1934 were aware of the "distributional consequences"); see also Ronald H. Coase, The Federal Communications Commission, 2 J.L \& ECON. 1, 33 ("Clarity of thought is even more difficult to achieve when we speak not of ownership of frequencies but of ownership of the ether, the medium through which the wave travels.").

30. See Carol M. Rose, Possession as the Origin of Property, 52 U. CHI. L. REv. 73, 74-75 (1985); but see Frank S. Rowley, Problems in the Law of Radio Communication, 1 U. CIN. L. REV. 1, 27-31 (1927) (arguing that the analogy to appropriating running water is not applicable to radio frequencies).

An example of the use of the first-in-time principle in American common law is the well-known case of Pierson v. Post., 3 Cai. R. 175 (N.Y. Sup. Ct. 1805) (holding that the first to capture a wild animal on unowned land is the owner); see also Richard A. Epstein, Possession as the Root of Title, 13 GA. L. REV. 1221, 1227-28 (1979) (arguing that most theories of property actually rest on "first possession").

31. See R. H. Coase, supra note 29, at 2 (describing the chaotic world of wireless radio communications prior to government regulation of radio frequencies). The circumstances surrounding the Titanic disaster are an example of the conflict between the Navy and amateur broadcasters. After a telegraph station in Newfoundland had received distress signals from the Titanic, many radio operators on the East Coast began to transmit messages. The high traffic on the electromagnetic spectrum caused interference and made communication with the Titanic nearly impossible. See THOMAS G. KRATTENMAKER, TELECOMMUNICATIONS LAW AND POLICY 3-4 (1994).

32. See Matthew L. Spitzer, The Constitutionality of Licensing Broadcasters, 64 N.Y.U. L. REV. 990, 1046 (1989) (arguing that common law property doctrines could have been used to adjudicate conflicts between uses of the electromagnetic spectrum for broadcasting). 
among users of the electromagnetic broadcast spectrum were addressed by Congress' passage of the Radio Act of 1912.33 The Act attempted to solve the problem of too many broadcasters vying for too few frequencies by prohibiting broadcasting without a license. ${ }^{34}$

The Radio Act of 1912 contained the seeds of the public trust model. Although it did not exphicitly rely on public ownership, ${ }^{35}$ it introduced administrative allocation of the broadcast spectrum, ${ }^{36}$ which is central to the pubhic trust model. In addition, provisions of the Act led to a situation in which the electromagnetic spectrum became even more scarce, making increased government control desirable. ${ }^{37}$ While the Act gave the Secretary of Commerce authority to hcense broadcasters, it had not given him authority to provide for the exclusive assignment of frequencies ${ }^{38}$ or to deny a right to use the electromagnetic spectrum. ${ }^{39}$ Without a means to exclude new broadcasters, the rapid proliferation of commercial radio broadcasters in the 1920 s created "chaos," as new broadcasters appropriated new frequencies as quickly as they

33. See Radio Act of 1912 , ch. 287, 37 Stat. 302 (1912); see also KRATTENMAKER, supra note 31, at 4 (listing key provisions of the Radio Act that would become the basis for all future broadcast regulations); Michael C. Rau, Comment, Allocating Spectrum by Market Forces: The FCC Ultra Vires?, 37 CATH. U. L. REV. 149, 150-51 (1987) (discussing history of radio regulation).

34. See 37 Stat. at 303.

35. See KratTenMaker, supra note 31, at 8 ("Although the 1912 Act had required a license to use the air, it had been silent on the issue of ownership of the airwaves."). But see Hazlett, supra note 29, at 135 ("The federal government was asserting ownership of the electromagnetic resource [through the Radio Act of 1912], but in a rather peculiar way.").

36. See Glen O. Robinson, The Federal Communications Act: An Essay on Origins and Regulatory Purpose, in A LEGISLATIVE HISTORY OF THE COMMUNICATIONS ACT OF 1934, at 3, 8 (Max D. Paglin ed.) (1989). The Radio Act was designed primarily to regulate ship-to-shore communications, and had not "set aside any particular frequencies for the use of private broadcast stations." NBC v. United States, 319 U.S. 190, 211 (1943). Despite this shortcoming, Herbert Hoover, as Secretary of Commerce, used the Radio Act as a basis for allocating rights to use the electromagnetic spectrum among commercial broadcasters. See $i d$.

37. See ITHEL de Sola POOL, TEChNOLOGIES OF FREEDOM 113-15 (1983).

38. See United States v. Zenith Radio Corp., 12 F.2d 614, 618 (N.D. Ill. 1926) (holding that under the Radio Act of 1912 the Secretary of Commerce has no power to promulgate regulations regarding exclusive use of the spectruin).

39. See Hoover v. Intercity Radio Co., 286 F. 1003, 1006 (D.C. Cir. 1923) (holding that Radio Act of 1912 did not grant the Secretary of Commerce discretion to withhold a license, even to protect against interference).

40. See Red Lion Broadcasting Co. v. FCC, 395 U.S. 367, 375 (1969) (stating that the pre-1927 allocation of frequencies by the private sector resulted in chaos). 
could build stations, and as existing broadcasters changed their frequencies and hours of broadcasting without warning. ${ }^{41}$

The disorganization prompted broadcasters, with the leadership of then Secretary of Commerce Herbert Hoover, to call for legislation to replace the Radio Act. $^{42}$ At the National Radio Conferences, convened for that purpose, representatives of the broadcast industry and other interested parties were adamant that the public owned the "ether." ${ }^{43}$ The Radio Act of $1927,{ }^{44}$ which was sliaped by discussions in the conferences, based the allocation of frequency riglits on public ownership of the electromagnetic spectrum. ${ }^{45}$ The provisions of the Radio Act were then incorporated into the Communications Act of $1934{ }^{46}$

Public ownership was justified on scarcity grounds, ${ }^{47}$ the drafters of the Communications Act reasoned that because the electromagnetic spectrum was an important resource that could not be made available to all who wanted it, it should be owned by the public. ${ }^{48}$ Those authorized to use the public's electromagnetic spectrum had special obligations. Their rights to use the electromagnetic spectrum were tied to obligations to serve the public interest; ${ }^{49}$ broadcast licensees were to be trustees for the public.

41. See J. Roger Wollenberg, The FCC as "Arbiter of The Public Interest, Convenience, and Necessity," in A LEgISLATIVE HISTORY OF THE COMMUNICATIONS ACT OF 1934, supra note 36 , at 61,66 (stating that, at one point, there were 732 licensed stations operating on only 90 channels); see also NBC, 319 U.S. 190, 210-14 (1943) (summarizing the history of government regulation of broadcasting).

42. See Robinson, supra note 36 , at 12 . Calls for legislation to replace the Radio Act led to a total of four National Radio Conferences between 1922 and 1926. See id. at 9.

43. See Wollenberg, supra note 41 , at 68 ("The ether is a public medium, and its use must be for public benefit.") (quoting Herbert J. Hoover's speech at the Fourth National Radio Conference in 1925).

44. Cl. 169, 44 Stat. 1162 (1927).

45. See id. \& 1, 44 Stat. at 1162; see also Hazlett, supra note 29, at 136 (stating that in 1927 "the government began to behave more like an actual owner").

46. See Wollenberg, supra note 41, at 61 ("[T]he basic provisions of [the Communications Act of 1934] were taken part and parcel from the Radio Act of 1927.").

47. See id. at 67 (concluding that the "startling notion" in Great Lakes Broadcasting v. Federal Radio Comm'n, 3 F.R.C. ANN. REP. 32 (1929), affd in part and rev'd in part, 37 F.2d 993 (D.C. Cir.), cert. dismissed 281 U.S. 706 (1930), was that the scarcity of the airwaves meant that public, rather than private, interests were chiefly at stake); see also $N B C, 319$ U.S. at 216 ("The facitities of radio are limited and therefore precious; they cannot be left to wasteful use without detriment to the public interest.").

48. See Wollenberg, supra note 41 , at 63-64.

49. See Spitzer, supra note 32, at 1008; see also Robinson, supra note 36, at 9 (stating that the development of broadcasting to the general public had introduced the notion of public service obligations). 
Thus the scarcity of the electromagnetic spectrum justified both the goal of broadcast regulation-a "commitment to the public interest" ship in which electromagnetic spectrum is essentially owned by the government, and, through licensing, is leased or temporarily granted to broadcasters. ${ }^{51}$ The concept of public ownership and service to the public interest is manifested through regulation of the structure of the broadcast industry, through administrative allocation of rights to use the electromagnetic spectrum for broadcast, and through regulation of the content that may be broadcast.

\section{A. The Public Trust Model and Broadcaster Identity}

The Communications Act of 1934 borrowed from the public trust doctrine both the prohibition of private ownership ${ }^{52}$ and the requirement of public access. ${ }^{53}$ The Act was designed to achieve comprehensive government control of broadcasting, ${ }^{54}$ which it did by creating a licensing scheme administered by the newly-created Federal Communications Commission (FCC) ${ }^{55}$ Although a hicense from the FCC was supposed to grant only a right to broadcast, and not a right to use the electromagnetic spectrum, ${ }^{56}$ the hicense included by default a right to use the electromagnetic spectrum. ${ }^{57}$

50. See Newton N. Minow, Commemorative Messages, in A LEGISLATIVE HisTORY OF THE COMMUNICATIONS ACT OF 1934, supra note 36 , at XV ("Without commitment to the public interest, all government action vis-á-vis communication would be without meaning.").

51. See Murray J. Rossini, Comment, The Spectrum Scarcity Doctrine: A Constitutional Anachronism, 39 Sw. L.J. 827, 828 (1985); Spitzer, supra note 32, at 1008.

52. See Pub. L. No. 73-416, § 301, 48 Stat. 1064, 1081 (1934).

53. See id. at 1088; see also Spitzer, supra note 32, at 1000-1003 (describing several public access provisions including the faimess doctrine, personal attack rules, and political broadcasting rules).

54. See $\S 301$, 48 Stat. at 1081 ("It is the purpose of this Act, annong other things, to maintain the control of the United States over all the channels of interstate and foreign radio transmission .....").

55. See $\S 318,48$ Stat. at 1089 ("No person shall operate [a radio transmission apparatus] except under and in accordance with an operator's license issued to him by the Commission."). The Federal Communications Commission replaced the Federal Radio Commission, which had been created by the Radio Act of 1927. See Wollenberg, supra note 41 , at 70 .

56. See $\S 310(\mathrm{~b}), 48$ Stat. at 1086 (treating a station license and "the frequencies authorized to be used by the licensee" separately).

57. The right to construct and operate a broadcast station was the only means of acquiring the right to use the portions of the electromagnetic spectrum which had been set aside for broadcasting. See $\S 319$ (a), 48 Stat. at 1089 (stating that a permit for con- 
In reality, broadcast licenses are, in part, licenses of a portion of the electromagnetic spectrum. Under the "public interest, convenience, and necessity" standard, broadcasters were required to operate as public trustees, using their portion of the electroniagnetic spectrum to advance the interests of the public. ${ }^{58}$

Public ownership and the public trust model also meant granting greater control to the Federal Communications Commission. The FCC, whicli determined whether particular broadcasters would serve or were already serving the public interest, was in this way acting as the public's representative. ${ }^{59}$ To the FCC, serving the public interest meant controlling who would broadcast by controlling the distribution of rights to use the electromagnetic spectrum. ${ }^{60}$ The FCC granted licenses based not only on neutral criteria such as price, but on five categories of more personal attributes and qualifications. ${ }^{61}$ These requirements inade it clear that whether a broadcaster could serve as a public trustee was a function not only of its ability to purchase the use of the resource, but also of its legal standing with the FCC, its technical ability, its character, and its citizenship. ${ }^{62}$ FCC policies dictated (and dictate) inquiry into character issues in both initial allocations and in renewal proceedings. ${ }^{63}$

The riglits granted to individual broadcasters have also been circumscribed by limiting transferability. A broadcaster's ability to transfer the right to use a particular frequency was implicitly limited by the personal requirements of licensing. ${ }^{64}$ In addition to

structing a broadcast station includes elements other than the frequency to be used for broadcast).

58. See KenNeth C. CREech, Electronic Media LaW and Regulation 70 (1993); Henry Geller, Communications Law-A Half Century Later, 37 FED. COMM. L.J. 73 (1985).

59. See Wollenberg, supra note 41 , at 61,78 .

60. See id. at 71 ("The Act also placed limits on who could hold licenses and to whom those licenses could be transferred."); see also Jonathan W. Emord, The First Amendment Invalidity of FCC Ownership Regulations, 38 CATH. U. L. REV. 401, 403 (1989) (criticizing the FCC's scarcity-based regime for imposing restrictions "based not upon the nature or content of speech but upon the characteristics of the speaker").

61. See CREECH, supra note 58 , at 81 .

62. See 47 U.S.C. § 308(b) (1994).

63. See generally In re Policy Regarding Character Qualifications in Broadcast Licensing, 102 F.C.C.2d 1179 (1986) (discussing the FCC's previous policies regarding inquiries into the character of licensees).

64. See id. at 1180 (stating that proposed transferees are subject to the same qualifications as are initial licensees). Ownership controls make transfer difficult because acquisition of the right is a result of status as well as of contract. See Robert C. Ellickson, 
these implicit limits, the Communications Act of 1934 expressly required FCC approval of license transfers. ${ }^{65}$ In 1962, the FCC added to the express limits of the Act by adopting a policy stating that it would require an administrative hearing for all proposed transfers of licenses that liad been lield for less than three years. ${ }^{66}$

The FCC exerted control over who would broadcast not only by controlling the clraracter of individual trustees, but also by controlling the identity of the broadcast industry as a whole. Policies proinulgated by the FCC limited the number of broadcast outlets that a broadcaster could own, ${ }^{67}$ and also tried to regulate the networks' influence over local stations. ${ }^{68}$

Property in Land, 102 YALE L.J. 1315, 1378 (1993) (claiming that property becomes a marketable commodity as groups move from relationships based on status to relationships based more on contract).

65. See $\S 309(b)(2), 48$ Stat. at 1085 ("Neither the license nor the right granted thereunder shall be assigned or otherwise transferred in violation of this Act."); id. $\S 310$ (b), 48 Stat. at 1086:

The station license required hereby, the frequencies authorized to be used by the licensee, and the rights therein granted shall not be transferred, assigned, or in any manner either voluntarily or involuntarily disposed of, or indirectly by transfer of control of any corporation holding such license, to any person, unless the Commission shall, after securing full information, decide that said transfer is in the public interest, and shall give its consent in writing.

66. See In re Amendment of Section 73.3597 of the Commission's Rules (Applications for Voluntary Assignments or Transfers of Control), 52 Rad. Reg. 2d 1081, 1081 (1982) (proposing to change the "three year rule," which it had adopted twenty years previously).

67. See In re Amendment of Section 73.3555 of the Commission's Rules Relating to Multiple Ownership of AM, FM and Television Broadcast Stations, 100 F.C.C.2d 17, 18 (1984) (discussing "seven station" rule, which prohibited any person or company from holding an interest in more than seven AM, seven FM, and seven TV stations). In addition to this prohibition, the FCC adopted a policy in 1964 that required an evidentiary hearing on any application for the acquisition of a VHF television station in one of the top 50 markets, if the applicant already owned or had interests in another station. See NAACP v. FCC, 682 F.2d 993, 996, 1003-04 (D.C. Cir. 1982) (describing the FCC's TopFifty policy and upholding the repeal of the policy against a challenge that the repeal would adversely effect minority ownership of television stations).

68. In 1970, the FCC promulgated the "Prine Time Access Rule" (PTAR), which attempted to reduce the influence of large networks by requiring stations to broadcast more local programming; it prohibited stations within the largest fifty television markets from using more than three hours of network programming per might of prime time. Kenneth C. Creech, Electronic Media Law and Regulation 167-68 (2d ed. 1996) [hereinafter CREECH 2D ED.]. This policy was recently changed, however. See In re Review of the Prime Time Access Rule, Section 73.658(k) of the Commission's Rules, 78 Rad. Reg. 2d (P\&F) 1076, 1101 (1995) (repealing PTAR on the basis that it was no longer necessary to promote independent program sources because of increasing numbers of non-broadcast outlets). 
Control over who would broadcast was also gained by circumscribing other characteristics of property rights. A broadcast hicensee was limited in its ability to exclude others froin broadcasting on its frequency ${ }^{69}$ In addition, rights granted under broadcast licenses were limited to three years. ${ }^{70}$ The duration of the riglit, while modified by renewal provisions, remained limited. The FCC could also revoke a license after it had been granted, and liad discretion over whether the term of the license was extended after the statutory period. ${ }^{71}$

In 1940, the Supreme Court clarified precisely how limited a commercial broadcaster's rights in the electromagnetic spectrum were. In FCC v. Sanders Brothers Radio Station, ${ }^{72}$ the Court unequivocally stated that the Communications Act of 1934 did not grant private property rights in the electromagnetic spectrum: "The policy of the Act is clear that no person is to have anything in the nature of a property right as a result of the granting of a license." $" 73$

\section{B. The Public Trust Model and Content Regulation}

The priority of public interests over private interests inherent in the public trust model was a cornerstone not only of regulations governing the identity of broadcasters, but also of regulations governing content. ${ }^{74}$ In both contexts, the priority of public rights

69. See Minasian, supra note 14, at 232 (explaining that the right to exclude refers to the right to refuse others permission to radiate energy on the owned spectrum). Under the 1934 Act, a broadcaster's right to exclude others from using its frequency was subject to qualifications for distress signals and for government use. One sending a distress signal could adjust the "transmitting set" so as to "produce a maximum of radiation irrespective of the amount of interference which may thus be caused," $\$ 321(\mathrm{a}), 48$ Stat. at 1090; one whose broadcast interfered with a government station had to cease transmitting for a portion of each hour. See $\S 323($ a), 48 Stat. at 1090.

70. See $\S 307(\mathrm{~d}), 48$ Stat. at 1084 ("No hicense granted for the operation of a broadcasting station shall be for a longer term than three years and no license so granted for any other class of station shall be for a longer term than five years . . ..").

71. See $\S 307(d), 48$ Stat. at 1084. An analogous situation in real property law shows how state discretion limits private property rights. When property rights in land subject to a public trust are granted, the state can later reassert title to fulfill its trust duties without that reassertion being considered a taking. In such a situation, the private landowner's rights in the land are rendered worthless because the state retains such a strong interest. See Douglas L. Grant, Western Water Rights and the Public Trust Doctrine: Some Realism about the Takings Issues, 27 ARIZ. ST. L.J. 423, 423 (1995).

72. 309 U.S. 470 (1940).

73. Id. at 475 .

74. See Fowler \& Brenner, supra note 15, at 213; see also Spitzer, supra note 32, at 
over private rights rests on the scarcity of the electromagnetic spectrum. ${ }^{75}$ Under the public trust model, broadcasters serve as trustees of the public, rather than representatives of their own private interests. ${ }^{76}$ This priority of public rights was evident not only in the Communications Act of 1934, but also in FCC rulemaking and in Supreine Court jurisprudence.

The Communications Act of 1934 contained a tension between the public interest and broadcasters' speech rights: it prioritized public over private interests while guaranteemg broadcasters freedoin froin censorship. ${ }^{77}$ The FCC responded to this tension by ruling that the statutory guarantee of freedom from censorship applied only to "speech deemed to be in the public interest."." In other words, conflicts between a broadcaster's right to speak and the public's rights as an audience were to be resolved by reference to the public's rights. As the FCC stated soon after the Communications Act of 1934 was passed, the statutory public interest standard required that the "interests of the listening public [be] paramount to the interests of the individual applicant." 79 This policy becaine an explicit part of FCC regulation in 1949, when the FCC stated that the "basic policy of the Congress" was that radio be

1054. Some examples of content regulation in the original Communications Act of 1934 were prohibitions against lotteries and against indecent communication. See Communications Act of 1934, Pub. L. No. 73-416, $\S \S 316,326,48$ Stat. 1088, 1091, repealed by Act of June 25, 1948, Pub. L. No. 80-772, § 21, 62 Stat. 683, 862. Nonetheless, content regulations of broadcasting still exist. See Hundt, supra note 11, at 1089-90; FCC v. Pacifica Found., 438 U.S. 726, 744 (1978).

75. See Richard E. Labunski, May it Rest in Peace: Public Interest and Public Access in the Post-Fairness Doctrine Era, 11 HASTINGS COMM. \& ENT. L.J. 219, 219-20 (1989).

76. Spitzer, supra note 32, at 1008 . While it may be more accurate to think of the priority of interests rather than the priority of rights when discussing soinething as amorphous as the public at large, the rhetoric in broadcast regulation and in First Amendment jurisprudence has been the rhetoric of rights, not the rhetoric of interests. See Denver Area Educ. Telecom. Consortium v. FCC, 116 S. Ct 2374, 2424 (1996); see also infra notes 92-101; PruneYard Shopping Ctr. v. Robins, 447 U.S. 74, 81 (1980).

77. See Communications Act of 1934, § 326, 48 Stat. at 1091:

Nothing in this Act shall be understood or construed to give the Commission the power of censorship over the radio communications or signals transmitted by any radio station, and no regulation or condition shall be promulgated or fixed by the Commission which shall interfere with the right of free speech by means of radio communication. No person within the jurisdiction of the United States shall utter any obscene, indecent, or profane language by means of radio communication.

78. CREECH, supra note 58 , at 56 .

79. In re Young People's Ass'n for the Propagation of the Gospel, 6 F.C.C. 178, 181 (1938). 
maintained "as a medium of free speech for the general public as a whole rather than as an outlet for the purely personal or private interests of the licensee." 80

The priority of public rights over private rights in the context of content regulation has allowed and entailed the imposition of limits upon broadcasters' editorial discretion that would be unconstitutional if applied to the print media. ${ }^{81}$ Limits on editorial discretion circumscribed a broadcaster's right to control use of a frequency by limiting what it could offer as programming. ${ }^{82}$ The FCC further limited editorial discretion by prescribing certain types of programming ${ }^{83}$ and by prohibiting broadcasters from broadcasting political editorials. ${ }^{84}$ In promulgating regulations against editorializing, the FCC reiterated that it was concerned with free speech as it related to the public, not as it related to broadcasters. It stated that broadcasters' discretion to

determin[e] the specific program material to be broadcast over their stations ... must be exercised in a manner consistent with the basic policy of the Congress that radio be maintained as a medium of free speecl for the general public as a whole rather than as an outlet for the purely personal or private interests of the licensee. ${ }^{85}$

These limits on rights to control use of the electroinagnetic spectrum were derived from the public trust model, as they seek to ensure, consistent with the ideal of public ownership, that any use is for public, not private, benefit.

80. In re Editorializing by Broadcast Licensees, 13 F.C.C. 1246, 1257 (1949) (emphasis added).

81. See Rossini, supra note 51, at 827. Compare Red Lion, 395 U.S. at $386-89,400$ (holding that broadcasters niay be required to grant rights of access to members of the public under certain circumstances) with Miami Herald Publ'g Co. v. Tornillo, 418 U.S. 241, 258 (1974) (holding that a newspaper is not required to grant a similar right of access, and that a Florida statute which required such access was unconstitutional).

82. For example, under the Communications Act of 1934, a broadcaster could not broadcast any information "concerning any lottery . . o or similar scheme." $\S 316,48$ Stat. at $1088-89$.

83. For example, broadcasters were required to schedule programs directed at children of different age groups and to limit the total number of commercials shown during children's programming. See Spitzer, supra note 32, at 1005. In addition, stations in certain markets were prohibited from using more than three hours of network programming per night of prime time. See id. at 1005-06.

84. See 47 C.F.R. $§ 73.1930$ (1995). The policy against editorializing was first enunciated in In re Mayflower Broad. Corp., 8 F.C.C. 333, 340 (1940).

85. See In re Editorializing by Broadcast Licensees, 13 F.C.C. at 1257. 
In addition to limiting a broadcaster's control over the use of the electromagnetic spectrum, limits on editorial discretion constrained a broadcaster's ability to exclude others from use of its broadcasting facility. ${ }^{86}$ For example, under the equal opportunity doctrine, codified in the original version of the Communications Act of 1934, if a broadcaster offered airtime to "any person who is a legally qualified candidate for any public office," then it was required to "afford equal opportunities to all other such candidates for that office." ${ }^{.87}$ Related to the equal opportunity doctrine is the Fairness Doctrine, which is perhaps the inost well-known limit on editorial discretion. ${ }^{88}$ The Fairness Doctrine had both statutory and administrative coniponents. As codified in 1959, the statute required a broadcaster to "afford reasonable opportunity for the discussion of conflicting views on issues of public importance." 89 Reporting on the Fairness Doctrine in $1974,,^{90}$ the FCC made it clear that the doctrine was based on the public trust model and the priority of the public's First Amendment rights: "[W]e do not believe that it would be appropriate-or even permissible-for a government agency charged with the allocation of the channels now available to ignore the legitimate First Amendment interests of the general public." ${ }^{\text {91 }}$ These limits on a broadcaster's ability to

86. See Andrew D. Auerbach, Mandatory Access and the Information Infrastructure, 3 COMMLAW CONSPECTUS 1, 3 (1995). Many FCC regulations "require broadcasters to relinquish their facilities [and by implication their portion of the electromagnetic spectrum] for use as a pulpit by others." Id. Note that while the right to exclude others is one of the most important characteristics of private property, see Minasian, supra note 14 , at 228 , it is bifurcated in broadcasting: in broadcasting, the right includes both the ability to exclude others from use of one's broadcast facilities and the ability to exclude others from the use of one's licensed portion of the electromagnetic spectrum. See supra note 17.

87. § 315,48 Stat. at 1088.

88. The Fairness Doctrine is an FCC policy that was codified when Congress amended the Communications Act of 1934 in 1959. See Labunski, supra note 75, at 229-30.

89. Cornmunications Act Amendments of 1959, Pub. L. No. 86-274, § 1, 73 Stat. 557, 557 (1959) (amending 47 U.S.C. $\$ 315$ ). In 1967, the FCC added two more aspects to the Fairness Doctrine: personal attack rules and limits on political editorializing. See CREECF, supra note 58 , at 64 .

90. When Congress amended section 315 of the Communications Act in 1959, it required the FCC to provide a yearly report of the Fairness Doctrine. See Pub. L. No. $86-274, \S 2$ (b), 73 Stat. 557, 557 (1959) codified at 47 U.S.C. § 315 (1994)).

91. In re the Handling of Public Issues Under the Fairness Doctrine and the Public Interest Standards of the Communications Act, 48 F.C.C.2d 1, 6 (1974) [hereinafter 1974 Faimess Doctrine Report]. 
exclude others were a manifestation of the public trust model's limits on private ownership.

The public trust model powerfully influenced the Supreme Court's holding in Red Lion Broadcasting Co. v. $F C C .{ }^{92}$ In Red Lion, the Court held that the First Amendment did not bar broadcast radio stations from being compelled to grant a right of access under the terms of the Fairness Doctrine. ${ }^{93}$ In analyzing the First Amendment issue, the Court viewed broadcasters as having vague First Amendment "interests," whicl liad to be weighed against the public's more compelling First Amendment rights. To the Court, broadcasting is simply "affected by a First Amendment interest;", it is "the right of the viewers and listeners, not the right of the broadcasters, which is paranount." der this analysis, any First Amendment rights that inhere in the use of the electromagnetic spectrum are vested in the public. Broadcasters hold their rights subordinate to those of the public because they serve as public trustees:

[A]s far as the First Amendment is concerned those who are licensed stand no better than those to whom hicenses are refused. ... There is nothing in the First Amendment which prevents the Government from requiring a licensee to share his frequency with others and to conduct himself as a proxy or fiduciary with obligations to present those views and voices. ${ }^{96}$

The access rights upheld in Red Lion were a result of the prioritization of the public's rights over those of private parties that is inherent in the public trust doctrine. ${ }^{97}$ This priority is also evident in other proposals for pubhic access to broadcast facilities. ${ }^{98}$ Arguments for these proposals depend on public ownership

92. 395 U.S. 367 (1969).

93. See 395 U.S. at $386-88,400-01$.

94. Id. at 386.

95. Id. at 390 (emphasis added).

96. Id. at 389.

97. See Auerbach, supra note 86 , at 3.

98. See, e.g., Dominic Caristi, The Concept of a Right of Access to the Media: A Workable Alternative, 22 SuFFolK U. L. REV. 103, 109-10 (1988) (suggesting that without public access rights, broadcasters exercise excessive control over a publicly-owned resource); Labunski, supra note 75 , at 225 (stating that broadcasters' use of a "limited public resource" should not go unregulated because "[s]carcity . . . is not dead"); Jeffrey A. Levinson, Note, An Informed Electorate: Requiring Broadcasters to Provide Free Airtime to Candidates for Public Office, 72 B.U. L. REv. 143, 162 (1992) (proposing that broadcasters be required to provide free airtime to political candidates); David Daley, 
of the electromagnetic spectrum. ${ }^{99}$ Proponents of broader public access begin with the premise that the electromagnetic spectrum is publicly owned, and proceed to argue that those who have been granted rights to use the spectrum have certain fiduciary obligations to the public. ${ }^{100}$ Focusing on public ownership in the first instance dictates that the public, as the owner of the airwaves, has a claim to a First Amendment right in the resource. ${ }^{101}$

\section{CRiticisms of the Public Trust Model}

The public trust model has been heavily criticized by broadcasters, economists, and civil libertarians. Nonetheless, it remained the principal mode of regulation throughout the 1950s, 1960s and most of the $1970 \mathrm{~s}^{102}$ In the late $1970 \mathrm{~s}$, however, emphasis on broadcasters as public trustees diminished while emphasis on broadcasters as market participants increased. ${ }^{103}$ Commentators

Rapoport Encourages Networks to Donate Prime Time Spots to Candidates, STATES NEwS SERV., Apr. 18, 1996, available in LEXIS, News Library, Curnws File (discussing the "Free TV for Straight Talk Coalition," which asked the major networks to set aside free airtime for presidential candidates and quoting Senator Bill Bradley as saying that the "public airwaves are a public trust ... and ... companies slould be called to their civic responsibility to use the airwaves to strengthen that democracy").

99. See supra note 98. But see Jerrome A. Barron, Access to the Press: A New First Amendment Right, 80 HARV. L. REV. 1641, 1656 (1967) (arguing for widespread public access to the mass media, including newspapers as well as broadcasting, on First Amendment, not public ownership, grounds).

100. See In re Inquiry into Section 73.1910 of the Commission's Rules and Regulations Concerning the General Fairness Doctrine Obligations of Broadcast Licensees, 102 F.C.C.2d 145, 146-47 (1985) (" $[I] n$ light of the limited availability of broadcast frequencies ... [ [w] determined that the need to effectuate the right of the viewing and listening public ... justifies restrictions on the rights of broadcasters."); Levinson, supra note 98 , at 165 ("[B]ecause broadcasters use a public resource, they have what resembles a fiduciary obligation to listeners and viewers.").

101. This analysis is much like that under the public forum doctrine in First Amendment law. See WILliam W. VAN AlstyNe, FirSt AMENDMENT 151 (2d ed. 1995) ("[The airwaves] are ... akin to a public park"); see also Spitzer, supra note 32, at 1038-41 (applying public forum analysis to broadcasting). Under the public forum doctrine, speech that takes place in a public forum provided by the government may be regulated by the government only according to reasonable and content-neutral time, place, and manner restrictions. See Ward v. Rock Against Racisin, 491 U.S. 781, 791 (1989) ("[E]ven in a public forum the government may impose reasonable restrictions on the time, place, or manner of protected speech.").

102. See Robinson, supra note 36, at 15-19. Deregulation of broadcasters, with a philosophy often opposed to the public trust model, began as early as 1972; Chairman Cliarles Ferris made it official policy under President Jimmy Carter. See CREECH, supra note 58 , at 75 .

103. See CREECH, supra note 58, at 75 . During the Reagan administration, under 
have criticized pubhic ownership and administrative allocation of rights to use the electromagnetic spectrum on the related grounds of property-based economics and First Amendment principles. At timies, property and free speech arguments overlap, as when property rights and First Amendment principles provide alternative methods of attacking the same broadcast regulations. ${ }^{104}$ Property and free speech arguments also overlap when the FCC is criticized for using structural regulations to implement content preferences. ${ }^{105}$

\section{A. Criticisms from Economics}

Those who use economics to criticize the public trust model emphasize the inefficiencies and skewed incentives that attend administrative allocation of public property. ${ }^{106}$ Of commentators who have criticized the economics of the public property approach to spectrum allocation, ${ }^{107}$ Ronald Coase is one of the most wellknown. In The Federal Communications Commission, Professor Coase criticized the decision in the 1920s to control disorganization in broadcasting through administrative allocation of licenses. ${ }^{108}$ $\mathrm{He}$ argued that it was not a lack of government control which caused the "chaos" in spectrum usage in the 1920s. The "real cause of the trouble was that no property rights were created in [electromagnetic spectrum]."109

Chairman Mark Fowler, the FCC pursued a program of "unregulation." See id.

104. For example, in Trinity Methodist Church v. Federal Radio Comm., 62 F.2d 850, 852-53 (D.C. Cir. 1932), a broadcaster challenged the FRC's denial of its license on grounds that it was both a taking of private property under the Fifth Amendment and a denial of free speech under the First Amendment. See id. Although the court denied both claims, id. at 851 , Trinity Methodist demonstrates that property and free speech arguments can be alternative methods to attack regulations.

105. See Auerbach, supra note 86, at 12-13 ("Thus, the government used a structural regulation as a vehicle to reflect its content preferences."); see also Coase, supra note 29 , at 7 (criticizing aspects of public ownership on both free speech and economic grounds).

106. See, e.g., LEVin, supra note 14, at 85 ("Few would deny that the present centralized nonprice spectrum system is economically imefficient or that it fails to further many overriding national priorities. Without markets and prices for radio frequencies, it is impossible to tell whether spectrum has been allocated optinally among alternative users and uses."); Minasian, supra note 14, at 222 ("It is an inflexible system that gives rise to inefficient allocation."); Hazlett, supra note 29, at 133 (noting that administrative allocation confers "significant economic rents on private parties at substantial opportunity cost to the fisc.").

107. See Coase, supra note 29, at 14 . But see Hazlett, supra note 29 , at 145.

108. See Coase, supra note 29 , at 17-24.

109. Id. at 14, 25. Not everyone agrees with Coase, however. One commentator has 
Administrative allocation has been criticized for several reasons. One is that allocation decisions are made without adequate information, ${ }^{110}$ and therefore without adequate evaluation. ${ }^{111}$ Without proper evaluation of cost, benefit, and consumer preferences, administrative allocation is "incapable of guiding the resource[] into its highest valued alternative."112 Lack of information is not the only difficulty; critics say that incentives inherent in the administrative scheme skew allocation decisions by both the FCC and broadcasters. ${ }^{113}$ Broadcasters' decisions are skewed because they do not pay the real cost for their rights to use the electromagnetic spectrum. ${ }^{114}$ Administrative allocation "raise[s] the income of station operators above what it would have been in competitive conditions." $" 115$ In addition, because broadcasters gain the rights to use the electromagnetic spectrum without cost, they have no incentive to economize such use. ${ }^{116}$ Politics have an even more troubling effect on incentives. Unlike inarket allocation, in which resources are allocated based on neutral criteria such as price, administrative allocation leaves room for political pressure. ${ }^{117}$

According to some critics, the solution to the problems inherent in administrative allocation is a property rights scheme. ${ }^{118}$

argued that the drafters did not need to create property rights; they only needed to recognize existing property rights. See Hazlett, supra note 29, at 145 (stating that "[p]roperty rights were no mystery in [the 1920's radio] market"). In Tribune Co. v. Oak Leaves Broadcasting Station, 68 Cong. Rec. 216 (1926) (reprinting an Illinois Circuit Court decision of Nov. 17, 1926), a chancellor in equity enjoined a new broadcaster from transmitting on any wavelength closer than fifty kilocycles from existing broadcaster WGN. Both plaintiff and defendant argued that using the spectrum, investing resources, and building a listenership gave the broadcaster a type of property right, recognized and enforceable in equity. Id. See also Spitzer, supra note 32, at 1046.

110. See Coase, supra note 29 , at 18.

111. Minasian, supra note 14 , at 221 .

112. Id. at 221; see also Coase, supra note 29 , at 18-19.

113. See Coase, supra note 29 , at 18 (arguing that FCC adopts rules in order to simplify its tasks, and that it is exposed to political pressure); PooL, supra note 37, at 13940 (arguing that the present system enables the state to license those whose message it prefers and that licensees make windfall profits).

114. See LEVIN, supra note 14, at 225-26; William K. Jones, Use and Regulation of the Radio Spectrum: Report on a Conference, 1968 WASH. U. L.Q. 71, 81-83 (1968).

115. Coase, supra note 29 , at 22.

116. See Jones, supra note 114 , at $82-84$.

117. See Coase, supra note 29, at 18; POOL, supra note 37, at 139.

118. See Coase, supra note 29 , at 25-34; Jones, supra note 114, at 85-97; DAVID KELley \& ROGer DONWAY, LAISSEZ PARLER: Freedom IN THE ELECTRONIC MEDIA 8, 43 (1983); Minasian, supra note 14, at 222-23; Richard W. Stevens, Comment, Anarchy 
These critics envision a limited role for the government and the legal system; one commentator has stated that the province of the legal system in allocation should be to "establish that clear delimitation of rights on the basis of which the transfer and recombimation of rights can take place through the market."119 If rights were thus delimited, market transactions could occur. ${ }^{120}$ Property rights transactions would, they argue, tend to maximize the value of production and to allow financial incentives to allocate electromagnetic spectrum to its most valued use. ${ }^{121}$

The property rights reforms suggested by broadcast regulation critics have not been implemented; they have nonetheless been influential as broadcast regulation has shifted from the public trust model toward the private market model, with a concomitant shift from rehance on public ownership to rehance on private property rights.

\section{B. Criticisms from the First Amendment}

The public trust model meant not only that the FCC could control, through administrative allocation, who was able to broadcast, but also that it could control the content of what was broadcast. ${ }^{122}$ The priority of the public's speecl rights over those of broadcasters was clear in the rletoric of Red Lion Broadcasting Co. v. FCC. ${ }^{123}$ Responses to the Red Lion decision have been varied. ${ }^{124}$ Some commentators have reacted by embracing the principle of public access, arguing that all members of the public should liave access to broadcast communication facilities, access not subject to the control of a broadcast licensee. ${ }^{125}$ Others have

in the Skip Zone: A Proposal for Market Allocation of High Frequency Spectrum, 41 FED. COMM. L.J. 43, 43 n.1 (listing autliors who have proposed systems of property rights).

119. Coase, supra note 29 , at 25 .

120. See id. at 27 ("[T]he delimitation of rights is an essential prelude to market transactions.").

121. See id.; Minasian, supra note 14 , at 221-22.

122. See supra note 74 (providing examples of content regulations to which broadcasters are subject).

123. 395 U.S. 367 (1969).

124. See POOL, supra note 37, at 122 ("The dilemma of free speech on a scarce medium left even ardent civil libertarians in conflict."); see also infra notes 125-26 (citing different responses to the Red Lion decision and the problem of access).

125. See generally Barron, supra note 99 (arguing for a right of access to the press, including broadcasters, based on First Amendment principles); Labunski, supra note 75, at 
argued the opposite: that the Supreine Court was wrong in not extending to broadcasters the same editorial discretion enjoyed by their colleagues who use print. ${ }^{126}$

Conflicting responses to Red Lion can be understood as disagreement or confusion about property rights. On the one hand, commentators who argue for public access to the electromagnetic spectrum premise their arguments on public ownership. They would prefer that the rights, especially speech rights, that inhere in the use of the electromagnetic spectrum be vested in the public. For example, Jerrome Barron argues that the First Amendment requires that the public have an opportunity to speak and to be heard. ${ }^{127}$ Others argue that the free market of ideas and the public's need to make informed voting decisions require that pohtical candidates be given time to air their views. ${ }^{128}$

On the other hand, those who argue for increased editorial discretion for broadcasters often premise their arguments on private ownership rights. They argue that the rights, including speech rights, that inhere in the use of the electromagnetic spectrum should be vested in broadcasters rather than the public at large. ${ }^{129}$ These commentators also criticize the current system of broadcast regulation as inconsistent with the First Amendment. ${ }^{130}$ Some of these commentators argue that government ownership of

277-78 (listing proposals for access to broadcast facilities); Levinson, supra note 98 (arguing that broadcasters should be required to provide free airtime to political candidates); Daley, supra note 98 ("The world's greatest democratic government has lent the right to the airwaves to certain companies, and those companies should be called to their civic responsibility to use the airwaves to strengthen that democracy." (quoting then U.S. Senator Bill Bradley)).

126. See Spitzer, supra note 32 (arguing that the licensing regime is inconsistent with the First Amendment because of the limits it places on broadcasters' editorial discretion); Fowler \& Brenner, supra note 15 (arguing that it makes no sense for the First Amendment rights of the public to have priority over those of the speakers, the broadcasters).

127. See Barron, supra note 99 , at 1666-78.

128. See POOL, supra note 37, at 121; Levinson, supra note 98, at 164-65; Daley, supra note 98; see also Nevel, supra note 13, at D-1 (describing a bipartisan group's request that influential broadcasters offer free airtime to political candidates).

129. See generally, KELLEY \& DONWAY, supra note 118, at 43 (arguing that "only a free inarket in communications media, services, and products, based on the recognition of property rights, can accommodate and preserve the different dimensions of freedom: economic, intellectual, and political"); Rossini, supra note 51, at 838-39 (discussing property proposal as a solution to criticisms based on the scarcity rationale).

130. See KELLEY \& DONWAY, supra note 118, at 27-33 (criticizing public rights of access); Poor, supra note 137, at 139 (criticizing the broadcast licensing system for creating censorship). 
a resource necessary to the public's communication is the essential problem, ${ }^{131}$ and that the power to license inherently involves censorship. ${ }^{132}$ As one such critic said: "So long as the [Commission] can determine which individuals shall be endowed with larynxes it does not need additional power to determine what shall be said." 133

Critics who argue for increased editorial discretion also point to the incongruence between First Amendment jurisprudence as it is applied to broadcast and print journahists. ${ }^{134}$ Unlike publishers of print, broadcasters must be licensed by the government, ${ }^{135}$ with resulting restrictions that range from limits on excluding views contrary to their own ${ }^{136}$ to prohibitions on the use of "indecent" language. ${ }^{137}$ One of the most influential critics in this area has been Ithiel de Sola Pool. ${ }^{138}$ Pool notes that in the days leading up to the Radio Act of 1927, there was consensus between radio station operators and the government on the need for regulation, ${ }^{139}$ and on the undesirability of censorship. ${ }^{140}$ Nonetheless, broadcasters have not enjoyed the same freedom as have other journalists, and Pool has observed that "[i]t is hard to reconcile

131. See Spitzer, supra note 32, at 1042 (arguing that the First Amendment requires private ownership of communication resources.)

132. See PooL, supra note 37, at 122 (referring to the Radio Act of 1927); Spitzer, supra note 32, at 1060 (" $[\mathrm{I}] \mathrm{t}$ would be safer for First Amendment values if the government sold all the spectrum and then bought whatever it needed in the market."). Even in 1927, Radio Commissioner Henry Bellows commented that "[t]he physical facts of radio transmission compel what is, in effect, a censorship of the most extraordinary kind." POOL, supra note 37, at 123 (quoting FEDERAL RADIO COMMISSION, ANNUAL REPORT FOR FISCAL YEAR 1927, at 6 (1927)).

133. Id. at 122 (quoting Morris Ernst).

134. Critics point to the divergence between the Supreme Court's approach in Miami Herald Publishing Co. v. Tornillo, 418 U.S. 241, 257-58 (1974), in which the Supreme Court struck down a right of reply statute as it applied to newspapers, and its approach in Red Lion Broadcasting Co. v. FCC, 395 U.S. 367, 400-01 (1969), in which the Supreme Court upheld a right of reply statute as part of the faimess doctrine. See Spitzer, supra note 32, at 994-1006 (listing restrictions on broadcasting as distinguished from print media).

135. See 47 U.S.C. \& 307 (1994).

136. See 47 U.S.C. \& 315 (1994); Auerbach, supra note 86, at 3 (calling it the "equal opportunities rule").

137. See FCC v. Pacifica Found., 438 U.S. 726, 748-51 (1978) (upholding an administrative ban on indecent language in broadcasting during certain hours).

138. See Hazlett, supra note 29, at 133.

139. See PooL, supra note 37 , at $116-18$.

140. See id. at 116-17. 
such governmentally imposed requirements with the traditional concept of the freedom of the press." 141

Mark Fowler, former Chairman of the FCC, and David Brenner have criticized what they see as the subordination of a broadcaster's editorial discretion to the "perceived needs of the general public for access to expression over the airwaves"142 on two grounds. First, they argue that First Amendment rights should vest in an active speaker (the broadcaster), rather than with the passive receiver (the listening public). ${ }^{143}$ Second, they argue that subordinating editorial discretion, and thus a broadcaster's First Amendment rights, to the public's needs potentially "prove[s] too much." If If a listener's First Amendment riglits are superior to a broadcaster's First Amendment rights, then "the rights of newspaper readers should be paramount to the rights of the pubhishers and editors and the rights of movie patrons superior to those of exhibitors." 145

Many critics of First Amendment doctrine in broadcasting have advocated a solution grounded in private property rights. ${ }^{146}$ They have argued that shifting property rights in the electromagnetic spectrum away from the pubhic or government and toward broadcasters would solve the inconsistencies or incompatibility between free speech principles and regulation based on licensing. ${ }^{147}$ One commentator has argued that market allocation is superior to administrative allocation because state licensing inevitably means state censorship. ${ }^{148}$ Another has stated: "Censorship can be, and is brought about by limiting the rights of private property."149

The reforms suggested by these critics of public ownership and administrative allocation have not been implemented, or at least have not been implemented in their entirety. The FCC still decides which portions of the electromagnetic spectrum will be used for

141. Id. at 135 .

142. Fowler \& Brenner, supra note 15 , at 237.

143. Id. at 237-38.

144. Id. at 238 .

145. Id.

146. See Kelley \& Donway, supra note 118, at 43; Bruce M. Owen, Radio and Television, in Free But Regulated: CONFlicting Traditions IN MEdia LAW 35, 39

(Daniel L. Brenner \& William L. Rivers eds., 1982); Spitzer, supra note 32, at 1068.

147. See Owen, supra note 146 , at 39 .

148. See POOL, supra note 37, at 139.

149. Minasian, supra note 14 , at 268. 
broadcasting and which will be used for other purposes. The present permutation of the Communications Act of 1934, as amended by the Telecommunications Act of 1996, continues to forbid users of electromagnetic spectrum from acquiring a property right in electromagnetic spectrum or in a broadcast license. ${ }^{150}$ Broadcasters continue to be subject to restrictions on the content they broadcast. ${ }^{151}$ Nonetheless, these criticisms of administrative allocation have influenced the shift from the public trust model to the private market model, and from public to private property rights in the broadcast spectrum. ${ }^{152}$

\section{TOWARD THE PRIVATE MARKet Model}

Despite the statutory ban on private ownership of the electromagnetic spectrum, broadcasters are no longer treated as trustees of public property. Instead, spectrum users and the FCC operate as if spectrum licensees are private parties with imterests in a valuable, scarce resource. ${ }^{153}$ Although broadcast regulation was originally premised on public ownership of the electronnagnetic spectrum, private parties now have stronger, more secure rights in the spectrum. The shift from a public trust model to a private inarket model, and the resulting shift from public ownership to private property rights, has occurred in three contexts: administrative practices of the FCC, legislative changes by the FCC and Congress, and free speech doctrine under the First Amendment. As a result of this shift, broadcasters' rights to use the spectrum have been strengthened and now more closely resemble private property rights. Specifically, broadcasters enjoy increased rights to control the use of their portion of the spectrum, to exclude use by others, and to exercise discretion in acquisition and transfer. In addition,

150. See Telecommunications Act of 1996, Pub. L. No. 104-104, § 336(d), 110 Stat. 56, 108 (1996). But see supra notes 3-7 and accompanying text (arguing that the Telecommunications Act of 1996 treats current licenses as exchangeable rights that function like private property rights).

151. See, e.g., FCC v. Pacifica Found., 439 U.S. 726.

152. See In re Cowles Florida Broad., Inc. 60 F.C.C.2d 372, 445 (1976) (Robinson, Comm'r, dissenting) (citing Professor Coase and arguing that broadcast licenses should be auctioned and recognized as private property rights).

153. See infra notes $175-85$ and accompanying text; see also Michael J. Hirrel, Oil and Vinegar: The FCC and the D.C. Circuit, 3 COMMLAW CONSPECTUS 121, 124 (1995) (stating that the way the FCC is viewed has changed from balancing private interests solely against the public interest to acting as "an arbiter of competing private interests"). 
these rights are made more secure because they can be held for an extended duration.

\section{A. Expansion of Private Property Rights Through the Reliance Interest}

The shift toward the private market model has been, in part, a result of the tendency of broadcast hicensees and the FCC to maintain the status quo. Paradoxically, however, maintenance of the status quo has changed the way both the FCC and broadcasters think about the rights granted by a license; it also has changed the way that rights to use the electromagnetic spectrum are acquired and transferred. ${ }^{154}$ Behind the facade of the Communications Act of 1934, actions by both private broadcasters and the FCC have strengthened broadcasters' rights in spectrum and have helped to create an informal, or shadow, market for spectrum as a transferable resource. ${ }^{155}$ Thus, broadcasters now more closely reseinble coinpeting players in a market than they do public trustees.

1. Renewal Expectancy. The tendency to maintain the status quo can be explained by the "reliance interest."156 As Professor Joseph Singer has said, "[n]on-owners who have relied on a relationship with the owner that made ... access [to a resource] possible in the past may be granted partial or total immunity from having such access revoked when this is necessary to achieve justice."157 Reliance interests create property rights through judicial recognition that an ongoing relationship has rendered a party vulnerable to injurious changes. ${ }^{158}$ In broadcasting, the relationship between broadcasters and their regulators (Congress and now the FCC) dates back to the process leading up to the

154. See LEVIN, supra note 14 , at 113 .

155. See infra notes $175-85$ and accompanying text.

156. See Singer, supra note 20 , at $619-20$ (discussing case in which plaintiffs argued that a property right "has arisen from the long-established relationship" between the parties). An administrative law case, Ruckelshaus v. Monsanto, 467 U.S. 986 (1984), provides an example of a reliance interest at work. In Ruckelshaus, the Supreme Court determined that whether a right should be considered a property right for the purpose of due process depended in part on whether the holder of the right could demonstrate that it I ad "reasonable, investment-backed expectations" in the property. Id. at 1005.

157. Singer, supra note 20 , at 699.

158. See id. at 621 . 
Radio Act of 1927.159 Whether the vulnerability created by this relationship must be recognized in order to avoid injustice is an open question. Nonetheless, the relationship between broadcasters and their regulators seems in fact to have created an implicit guarantee that broadcasters' licenses will not easily be revoked by the government. ${ }^{160}$

This reliance interest is evident in the FCC policy of granting a "renewal expectancy" to incumbent licensees in comparative liearings. ${ }^{161}$ Comparative hearings arise when there are two mutually exclusive applications for the same license. ${ }^{162}$ Rather than automatically renewing the incumbent's broadcast license, the FCC arranges to hold a liearing in which it determines which of the two or more applicants is best able to serve the public interest. ${ }^{163}$ To make this determination, the FCC examines many factors, such as service to the community, previous compliance with FCC content regulations, and the concentration of media in that particular area. ${ }^{164}$ Granting a renewal expectancy means that in a comparative learing, an incumbent broadcaster lias an advantage over a clallenger, provided that the incumbent's past perforinance does not contain "serious deficiencies." Altho Although the FCC's statement of this policy was struck down as a dernal of administrative due process, ${ }^{166}$ the Court of Appeals for the District of Columbia

159. See KRATTENMAKER, supra note 31, at 5-7; Hazlett, supra note 29 , at 153-54.

160. See Telecommunications Act of 1996, § 204(a)(4), Pub. L. No. 104-104, 110 Stat. 113 (1996) (amending 47 U.S.C. $\$ 309$ ) (prohibiting consideration of a competitor in a proceeding to renew a broadcaster's license).

161. See CREECH 2D ED., supra note 68, at 124-27.

162. See Spitzer, supra note 32, at 997-98.

163. See CREECH 2D ED., supra note 68 , at 124.

164. Policy Statement Concerning Comparative Hearings Involving Regular Renewal Applicants, 22 F.C.C.2d 424, 424-27 (1970) [hereinafter Comparative Hearing Policy Statement].

165. See id. at 428. It is unclear what "serious deficiencies" are, since the FCC rarely refuses to renew a license. See CREECH 2D ED., supra note 68, at 124-25.

The FCC's policy of giving preference to an incumbent over a new applicant in a comparative renewal hearing was stated in a 1951 case, In re Hearst Radio Inc. (WBAL), 15 F.C.C. 1149 (1951). The policy did not provide the degree of protection that broadcasters would have liked for their investments, and so the broadcast lobby attempted to convince Congress to amend the Communications Act. After an amendment to the Communications Act naking renewal expectancy both strong and autonatic failed to pass Congress, the FCC adopted a Policy Statement to the same effect in 1970. See CREECH 2D ED., supra note 68, at 126.

166. See Citizens Communications Ctr. v. FCC, 447 F.2d 1201, $1205-06$ (D.C. Cir. 1971) (lolding that policy statement violates Ashbacker doctrine, which requires a full hearing when mutually exclusive applications are filed). 
Circuit held that superior performance by an incumbent could still be regarded as a "plus of major significance."167 Thus, while the FCC may not raise renewal expectancy to an "irrebuttable presumption in favor of the incumbent,"168 "some degree of renewal expectancy is permissible."169

Whatever the precise doctrinal formulation of the renewal expectancy, in practice broadcast licenses are routinely renewed. ${ }^{170}$ Current FCC Chairman Reed Hundt has stated that in renewal proceedings for broadcast television hicenses, the FCC has renewed "almost every single broadcast license at least three times, and has taken away not one license for failure to provide public interest programming." 171 Routine renewal with seemingly hittle scrutiny arises in part because both the grantor (the FCC) and the grantee (the broadcaster) have a strong incentive to rely on the current allocation of riglits. As former Chairman Fowler has said, "Both the license renewal rate and the profits for most of the broadcasting business have been so high that neither the regulated nor the regulators have been anxious to challenge the system."172

Renewal expectancy strengthens a broadcaster's riglit in the electromagnetic spectrum by extending the duration of the right. In the 1990s, an imcumbent licensee who has been granted a renewal expectancy is insulated from challenges by competitors who seek access to the portion of the spectrum to which the incumbent currently has rights. ${ }^{173}$ Although this expansion of a property

167. Citizens Communications Ctr., 447 F.2d at 1213.

168. Central Florida Enters., Inc. v. FCC, 683 F.2d 503, 506 (D.C. Cir. 1982). In 1989 the FCC issued a proposed rule designed to clarify its policy. The proposed rule provided for a rebuttable presumption that the incumbent licensee had provided meritorious service. See CREECH 2D ED., supra note 68, at 127; see also In re Formulation of Policies and Rules Relating to Broadcast Renewal Applicants, Competing Applicants, and Other Participants to the Coinparative Renewal Process and to the Prevention of Abuses of the Renewal Process, 4 F.C.C.R. 7851, 7851 (1989) (stating that the FCC would continue to award renewal expectancy based upon the incuunbent's past meritorious service and calling for a new order of proof to apply such a standard).

169. Central Florida Enters., Inc., 683 F.2d at 506.

170. See CREECH 2D ED., supra note 68, at 126.

171. Hundt, supra note 11 , at 1094 . Renewal proceedings, which previously took place every three years, have taken place every five years since the late $1970 \mathrm{~s}$. Id. With the passage of the Telecommurications Act of 1996, radio and television broadcast licenses will be renewed every eight years. See Telecommunications Act of 1996, § 203, Pub. L. No. 104-104, 110 Stat. 112 (1996) (amending 47 U.S.C. § 307(c)).

172. Fowler \& Brenner, supra note 15, at 209.

173. This advantage promises to be even greater under the provisions of the Telecommunications Act of 1996. See $\S 204(a)(4), 110$ Stat. at 113 (amending 47 U.S.C. 
riglit has been cast in the language of the public interest and the public trust model ${ }^{174}$ it is in reality part of the shift toward the private inarket model. When government and the public have less of a residual right in the license, the coinciding right in the licensee is stronger.

2. Shadow Markets for Spectrum. Under the Communications Act of 1934, licenses to operate broadcast facilities-and thus rights to use the electroinagnetic spectrum-may not be transferred without FCC approval. ${ }^{175}$ When a transfer is granted, it is to include the transfer of only the station and its organization, since the "frequency is public property, and the grant of a license gives no rights of any sort in that frequency."176 However, these statutory limits lave failed to keep a market im electromagnetic spectrun from developing, in part because FCC policies liave implicitly accepted and even encouraged such a market. ${ }^{177}$ The inarket for electromagnetic spectrum is a sliadow market; rights to use the electromagnetic spectrum are transferred in the form of a transfer of broadcasting equipment. ${ }^{178}$

The creation of a inarket in electromagnetic spectrum, in contravention of the stated goals of the Communications Act of 1934, is encouraged, first, by the tension einbodied in the Act itself. Allocation decisions under the Communications Act of 1934 are inherently unstable; "[ $t]$ lie imitial method of selecting a license may have little effect on who ultimately lolds it."179 Although the FCC, as grantor of rights to use the electroinagnetic spectrun,

§ 309) (granting increased license terms and prohibitions on considerations of competitors).

174. See, e.g., Comparative Hearing Policy Statement, supra note 164, at 428-29 (using public trust language to justify a policy of routine renewal of broadcasting licenses).

175. See Communications Act of 1934, § 301, Pub. L. No. 73-416, 48 Stat. 1064, 1081 (1934) (codified at 47 U.S.C. $\S 301$ (1994)) ("It is the purpose of this chapter, among other things, to maintain the control of the United States over all the channels of radio transmission ... and no ... license shall be construed to create any right, beyond the terms, conditions, and periods of the license.").

176. Coase, supra note 29 , at 22.

177. See infra note 184 and accompanying text (in practice, FCC routinely grants transfers); see also supra text accompanying notes 154-74 (explaining how broadcasters lave developed a reliance interest in the electromagnetic spectrum with the encouragement of FCC policy).

178. See Pool, supra note 37, at 139.

179. Kwerel \& Felker, Using Auctions to Select FCC Licensees, in KRATTENMAKER, supra note 31, at 121, 123 (1994). 
bases allocation decisions on broadcasters' ability to serve as public trustees, broadcasters are not always motivated by fiduciary considerations. They expect not only to serve as public trustees, but also, primarily, to make a profit. ${ }^{180}$ Having received an economically valuable right for free ${ }^{181}$ broadcasters can profit from that windfall ${ }^{182}$ in one of two ways. They can operate radio or TV stations, making a profit by selling time to advertisers; or they can sell the rights to operate those stations-which implicitly include the rights to use those portions of the electromagnetic spectrum-for more than the amount they had paid. The Communications Act of 1934 souglit to prevent the latter by making transfers, like initial allocations, administrative rather than market decisions. ${ }^{183}$ Over time, however, the administrative component of transfers became less important; transfers are now nearly always approved. ${ }^{184}$ Over time, it also became clear that prices paid by buyers were not sunply for broadcasting equipment; "a great part of the purchase price is in fact payment for obtaining the use of the frequency." 185 The creation of a shadow market made clear that the electromagnetic spectrum was a resource that could be acquired and transferred through market inechanisins.

\section{B. Deregulation}

Deregulatory actions by the FCC and Congress have also increased the scope and the strength of private property rights in the electromagnetic spectrum. As discussed in Part II, the Communications Act of 1934 placed several limitations on use and control

180. See CBS v. Democratic Nat. Comm., 412 U.S. 94, 187 (1973) (Brennan, J., dissenting). (" $[\mathrm{I}] \mathrm{n}$ light of the strong interest of broadcasters in maximizing their audience, and therefore their profits, it seems almost naive to expect [them] to ... reflect a full spectrun of viewpoints."); James T. Hamilton, Comment: Private Interests in 'Public Interest' Programming: An Economic Assessment of Broadcaster Incentives, 45 DUKE L.J. 1177,1183 ("[B]roadcasters will choose to air programs that maximize . . profits.").

181. See LEVIN, supra note 14, at 85 (describing how the FCC "give[s] away" broadcast licenses).

182. Harvey Levin investigated the value of essentially "free" spectrum in the 1940s and 1950s. See id. By comparing earning rates in broadcasting with those in comparable "creative" industries like newspapers and magazines, he found that broadcasting profit margins (at least in AM radio and VHF television) were far in excess of corporations in other sectors. See id. at 367-68.

183. See supra notes $64-66$ and accompanying text.

184. See PoOL, supra note 37, at 139.

185. Coase, supra note 29 , at 22 . 
of a licensed portion of the spectrum. ${ }^{186}$ Deregulation, with its goals of increased competition and decisionmaking based on market criteria, ${ }^{187}$ forced a recognition of broadcasters' roles as marketplace competitors, as well as public trustees. ${ }^{188}$

One way to recognize broadcasters as entities competing in a market was to make allocation of rights to use the electromagnetic spectrum depend on market factors rather than administrative decisions. Administrative allocation based on the public interest standard was difficult to apply and drew criticism as beimg irrational, inefficient, and at odds with fundamental liberties. ${ }^{189}$ The first move toward market allocation of electromagnetic spectrum came in 1981, when Congress gave the Commission permissive authority "to award licenses by random selection." 190 Thus, lotteries had the effect of making licenses less like government-sanctioned privileges and more like resources that could be traded in a market. ${ }^{191}$

Market-based allocation via auctions was suggested in $1985^{192}$ and adopted in $1993 .^{193}$ Although auctions were only used to al-

186. Some of the most significant are: 1) The right to exclude others, including the government and those desiring "equal time," was limited; 2) spectrum was allocated based on government judgments-about matters such as a prospective broadcaster's character and alienage-rather than on price, which in turn limited transferability; 3) licensees had little ability to control use of their licensed portion of the electromagnetic spectrum; 4) the right was of short duration and had little immunity from government expropriation. See supra note 17 and accompanying text.

187. See Henry Geller, Foreword to The Telecommunications Deregulation SOURCEBOOK at viii (Stuart N. Brotman ed., 1987).

188. See Fowler \& Brenner, supra note 15, at 210 ("[T]he first step in a marketplace approach to broadcast regulation, then, is to focus on broadcasters not as fiduciaries of the public, as their regulators have historically perceived them, but as marketplace competitors.").

189. See generally supra Part II (detailing criticisms of administrative allocation of the electromagnetic spectrum).

190. Ervim S. Dingan, Spectrum Licensing in the '90s: Can We Find A Way?, Remarks before the American Mobile Telecommunications Association SMR Leadership Conference (June 24, 1992), available in 1992 FCC Lexis 3479 , at *8. Several problems with the lottery system arose, the most significant of which was that because rights were given away essentially for free, there were many more applications for licenses than there were licenses available. See id.

191. See generally Ellickson, supra note 64, at 1377-78 (arguing that property becomes a marketable commodity as groups move from relationships based on status to relationships based more on contract).

192. In 1985, then-Chairnan Fowler proposed to Congress that "spectrum be assigned through competitive bidding without regard to use." Duggan, supra note 190 , at $* 10$.

193. See J. Gregory Sidak, Telecommunications in Jericho, 81 CAL. L. REv. 1209, 1234 (1993). 
locate portions of spectrum not used for broadcasting, ${ }^{194}$ the use of auctions indicates a shift in FCC philosophy that is now working its way into broadcasting; recently, it was proposed that the spectrum for a new technology-high definition television, or HDTV-be auctioned. ${ }^{195}$ Allocating rights to use part of the electromagnetic spectrum based on price demonstrates that the electromagnetic spectrum as a whole, although it has long been considered to be owned by the public, is not immune from being sold to private bidders. Once acquired by private bidders, the right is more akin to a property right, or a commodity traded in a market, than to a government-sanctioned privilege. Using price as a - ineans of allocating rights is further evidence of the shift toward a private market model, since price allocation recognizes spectrum users as coinpeting private actors who function in a system that looks like a private enterprise system, rather than as public trustees. ${ }^{196}$

Changes in the way broadcasters acquire rights in the electromagnetic spectrum also affect transferability, again strengthening those rights. Since market factors are more neutral bases for allocation decisions, ${ }^{197}$ they allow for more potential buyers and more potential uses. FCC policies also have enabled more transfers to occur. Between 1962 and 1982, broadcasters were subject to the "antitrafficking rules," which limited transferability in an attempt to control speculation in licenses. ${ }^{198}$ The antitrafficking rules re-

194. See id. Auctions first applied only to spectrum for Personal Communications Services (PCS). See id. Later, they also were used to allocate spectrum for Multipoint and/or Multichannel Distribution Service (MDS). See In re Amendment of Parts 21 and 74 of the Commission's Rules With Regard to Filing Procedures in the Multipoint Distribution Service and in the Instructional Television Fixed Service and Implementation of Section 309(j) of the Communications Act-Competitive Bidding, Report and Order, 10 F.C.C. Reg. 9589 (1995); Interactive Video Data Services (IVDS), and Direct Broadcast Satellite (DBS). See S. Jenell Trigg, The Federal Communications Commission's Equal Opportunity Employment Program and the Effect of Adarand Constructors, Inc. v. Pena, 4 COMMLAW CONSPECTUS 237, 241 (1996) (listing the services for which spectrum has been auctioned by the FCC).

195. In the spring of 1996, Bob Dole, then Senate majority leader, proposed that licenses for high-definition television (HDTV) be auctioned, rather than granted through administrative allocation. See Clay Chandler, In the Dole Tax Plan, Questions of Credibility, WASH. POST, Aug. 21, 1996, at F1.

196. See Coase, supra note 29, at 14 ("[A] private-enterprise system cannot function properly unless property rights are created in resources, and, when this is done, someone wishing to use a resource has to pay the owner to obtain it.").

197. See PooL, supra note 37 , at 139 (criticizing administrative allocation for its lack of neutrality among competing viewpoints).

198. See In re Amendment of Section 73.3597 of the Commission's Rules (Applica- 
quired that if a licensee wanted to transfer a license it had held for less than three years, not only did the FCC have to approve the transfer, but it had to set the apphication for a hearing. ${ }^{199} \mathrm{Al}-$ though the FCC rules did permit transfers, ${ }^{200}$ the hearing requirement reduced the extent to which a license "looked like" transferable property. After deregulation became a force in the late 1970 s and the early 1980s, the FCC relaxed the antitrafficking rules in $1982,{ }^{201}$ decreasing the time requirement for retention of a license, ${ }^{202}$ and making it easier for spectrum to be transferred to those who wonld value it more highly. In the process of relaximg its antitrafficking standards, the FCC also strengthened broadcasters' private property imterests in spectrum.

For broadcasters, deregulation also meant increased rights to control their use of the electromagnetic spectrum. Increased control involves both increased editorial discretion, in the form of autonomy in format and programming decisions, ${ }^{203}$ and an increase in cloices regarding the use to which a portion of the electroinagnetic spectrum would be put. Motivated by a desire to deregulate the broadcast imdustry, the FCC stated that it would no longer mandate certain types of radio programming that would serve the public interest and would no longer review format changes (i.e., whether a radio station played classical or popular music). ${ }^{204}$ The U.S. Supreme Court upheld the FCC's authority to make this clange in FCC v. WNCN Listeners Guild. ${ }^{205}$ In $W N C N$, the Court stated that market forces and competition, rather than administrative rules, were best able to serve the public interest in diverse programming. ${ }^{206}$

Also as a result of deregulatory initiatives, broadcasters now have increased control over liow to use their portion of the elec-

tions for Voluntary Assignments or Transfers of Control), 52 Rad. Reg. 2d (P\&F) at 1082.

199. See id.

200. See id. at 1082 .

201. See 52 Rad. Reg. 2d (P\&F) at 1086-87.

202. Id. at 1087-88.

203. See In re Deregulation of Radio, 84 F.C.C.2d 968, $977-83$ (1981) (eliminating many guidelines for radio broadcasters, including minimal amounts of non-commercial programming); FCC v. WNCN Listeners Guild, 450 U.S. 582, 593 (1981) (upholding an FCC policy of no longer considering format changes as an adverse factor in license renewals and transfers).

204. See In re Deregulation of Radio, 84 F.C.C.2d at 968.

205. 450 U.S. 582 (1981).

206. See id. at 603 . 
tromagnetic spectrum. ${ }^{207}$ While the FCC still designates which portions of the electromagnetic spectrum should be used for which purposes, ${ }^{208}$ the trend brought about by deregulation is to allow licensees greater freedom in choosing how to use their allotted portion of spectrum. For example, the FCC allows broadcasters of $A M$ and FM radio to use their signals for other uses, such as teletext transmission, which will not interfere with "broadcast channel operation." 209 These sorts of arrangements use mechanisms which rely on competing private users-a marketplace approachrather than a standard which relies on a determination about which technology is best placed in which portion of the spectrum.

Deregulatory mitiatives have also strengthened private property rights in the electromagnetic spectrum by increasing their duration. Originally, the license term for radio and television was three years. ${ }^{210}$ In 1981, however, the guaranteed term of the license was extended to seven years for radio and five for television. ${ }^{211}$ Now, after the passage of the Telecommunications Act of 1996, broadcast licenses are granted for a term of eight years. ${ }^{212}$ Coupled with the renewal expectancy, ${ }^{213}$ a longer term provides a broadcast licensee with substantial certainty that it will continue to enjoy the use of the resource, while at the same time preserving much smaller residual rights for the grantors-the public.

A statement by former Commissioner Ervin S. Duggan demonstrates how even within discussions of public ownership, the public or government has a much smaller residual right in a

207. See Douglas Webbink, Radio Licenses and Frequency Spectrum Use Property Rights in KRATTENMAKER, supra note 31, at 55, 56; In re Amendment of Parts 2 and 73 of the Commission's Rules Concerning Use of Subsidiary Communications Authorizations, 97 F.C.C.2d 23, 25 (1984) [hereinafter FM Subsidiary Authorization]; In re Amendment of Parts 2 and 73 of the Commission's AM Broadcast Rules Concerning the Use of the AM Carrier, 100 F.C.C.2d 5 (1984) [hereinafter AM Subsidiary Authorization].

208. See Communications Act of 1934, 47 U.S.C. $\S 301$ (1994).

209. See AM Subsidiary Authorization, supra note 207, at 5; FM Subsidiary Authorization, supra note 207, at 1519 (FM stations may allow their signal-or their portion of the electromagnetic spectrum-to be used for other, noninterfering uses).

210. See CREECH, supra note 58, at 94.

211. See id.

212. Telecommunications Act of 1996, Pub. L. No. 104-104, § 203, 110 Stat. 56, 112. (amending 47 U.S.C. $\$ 307(\mathrm{c})(1)$ to provide that the term of a license for operating a broadcast station shall not exceed eight years).

213. See CREECH, supra note 66 , at 98 (noting that the policy of renewal expectancy gives the incumbent an advantage over the challenger in a comparative hearing); see also supra note 161 and accompanying text. 
broadcast license. In advocating auctions of broadcast spectrum, Duggan has said that the use of the spectrum should generate money "for the American people to whom the spectrum belongs," psychology,' in which licensees might come to see themselves as permanent owners, having 'bought and paid for' their spectrum."215 To preserve the ideal of public ownership, even within an allocation scheme that assumes private market participants, Commissioner Duggan suggested that policy be based upon the following analogy: "As a legal matter, FCC hicenses, even those awarded by auction, must never be viewed as outright sales; they are more akin to contracts or leases that revert automatically to the public domain if the terms are broken." ${ }^{216}$ However, by using the language of reverter, Commissioner Duggan tacitly admits that broadcasters enjoy much stronger property rights in the electromagnetic spectrum than they would if they were trustees of the public. ${ }^{217}$

\section{Changes in Content Regulation and First Amendment Doctrine}

Changes in content regulation and free speech doctrine under the First Amendment as it applies to broadcasting have paralleled changes in other areas of broadcast regulation. These changes either liave strengthened private property rights or have reflected already-enhanced private property rights. As broadcasters have been granted increased editorial discretion, they have been more able to control content and to control that portion of the spectrum which they have been licensed. ${ }^{218}$ Under the public trust model, limits on editorial discretion were justified on grounds that the public owned the electromagnetic spectrum. ${ }^{219} \mathrm{~A}$ shift away from the public ownership rationale, along with changes in the focus of First Amendment rights, has shifted broadcast content regulation toward the private market model.

214. See Duggan, supra note 190 , at $* 11$.

215. Id. at $* 13$.

216. Id. at $* 16$.

217. The language of reverter implies that the public is the holder of a reversionary interest, rather than the beneficiary of a trust.

218. See supra notes $\mathbf{8 1 - 8 5}$ and accompanying text (noting that lack of editorial discretion decreases private property rights).

219. See supra notes 81-101 and accompanying text. 
The high point of the priority of public over private rights in the electromagnetic spectrum was the Supreme Court decision in Red Lion Broadcasting Co. v. FCC. ${ }^{220}$ Soon after the Red Lion decision, however, the relative priority of public and private rights began to shift. In the first major First Amendment decision involving broadcasting after Red Lion, CBS v. Democratic National Committee, ${ }^{221}$ the Supreme Court limited the scope of Red Lion by holding that a broadcaster's policy of not selling advertising time to individuals or groups did not violate the First Amendment or the Communications Act. ${ }^{222}$ In doing so, it questioned the notion that public ownership means public access.223 The Court also adjusted the relative priorities of First Amendment rights that had been set forth in Red Lion and demonstrated a different perception of broadcasters than it previously had. No longer were the public's First Amendment riglits eitler "paramount" to those of broadcasters or implicitly the center of First Amendment analysis. This is evident in the Court's analysis, which focuses primarily on the First Amendment rights of broadcasters, rather than those of the public. Although the Court's opinion invokes the rationales of scarcity and the public trustee function, ${ }^{224}$ it only briefly mentions the public interest and then proceeds to focus on the First Amendment rights of broadcasters. ${ }^{25}$ Indeed, the Court's shift in priorities is apparent in its cliaracterization of the public's claim as an "interest" rather than a more significant "right."2226

According to the Court, the importance of the "journalistic discretion of broadcasters" dictated that broadcasters be enabled to make decisions about the content they broadcast. ${ }^{227}$ "For better or worse," the Court stated, "editing is what editors are for; and editing is selection and choice of material."228 $C B S$ strengthened broadcasters' editorial discretion, increasing their ability to control

220. Red Lion Broad. Co. v. FCC, 395 U.S. 367 (1969); see supra notes $92-97$ and accompanying text for a description of the Red Lion doctrine.

221. 412 U.S. 94 (1973).

222. See id. at $129-31$.

223. See id. at 105-06.

224. See id. at 101 (noting the "inherent physical limitation" caused by the scarcity of available electromagnetic spectrum); $i d$. at 111,118 (discussing the "public trustee" function of a broadcast licensee).

225. See id. at 120-22.

226. See supra note 76.

227. Id. at 124.

228. Id. 
their licensed portion of the electromagnetic spectrum. By focusing on broadcasters' First Amendment rights, the Court also demonstrated a new perception of broadcasters; it treated them as players in a marketplace of ideas, rather than as mere conduits for the ideas of the public.

In 1978, in FCC v. Pacifica Foundation, ${ }^{229}$ the Supreme Court further eroded the public trust model by ignoring the scarcity rationale, the rationale upon which the public trust model had been based..$^{230}$ At issue in Pacifica was whether the FCC had the power to regulate indecent radio broadcasts. ${ }^{231}$ The Court held that it did; neither the First Amendment nor Section 326 of the Communications Act, ${ }^{232}$ forbid the FCC to do so. $^{233}$ Under the First Amendment, the Court reasoned, the program in question (George Carlin's "Seven Dirty Words" monologue) was deserving of less than heightened scrutiny because of both its content and its context. ${ }^{234}$ The content of the program was indecent, ${ }^{235}$ and the program took place in the context of broadcast communication, the regulation of which is subject to less stringent constitutional limitations than print communication. ${ }^{236}$

In Pacifica, the Court took a fundamentally different tack than it had in Red Lion. It focused on broadcasters as speakers, rather than on the public as histeners, seeming to take for granted that the "speakers," and thus those whose First Amendment rights were being protected, were broadcasters. ${ }^{237}$ Most importantly, however, the Court's approach differed from Red Lion im that it did not rely on the scarcity rationale-the linchpim of the public

229. 438 U.S. 726 (1978).

230. See supra notes $47-51$ and accompanying text (discussing how the scarcity rationale underlies the public trust model of broadcast regulation).

231. See Pacifica, 438 U.S. at 735.

232. 47 U.S.C. $\$ 326$ (1994).

233. See Pacifica, 438 U.S. at 738, 748-51. Although section 326 prohibits FCC censorship, the FCC had found its power to regulate indecent broadcasting in two different statutes: 18 U.S.C. $\$ 1464$ (1976) (forbidding use of "any obscene, indecent, or profane language by means of radio communications") and 47 U.S.C. $\$ 303(\mathrm{~g})$ (1994) (requiring FCC to encourage "larger and more effective use of radio in the public interest").

234. See Pacifica, 438 U.S. at $747-48,750$.

235. See id. at 748-51.

236. See id. at 748 .

237. See id. "Thus, although other speakers cannot be licensed . . . a broadcaster may be deprived of his license and his forum if the Commission decides that such an action would serve "the public interest, convenience, and necessity."). 
trust model ${ }^{238}$ - to explain why broadcasted speech was subject to decreased First Amendment protection. Abandoning the scarcity rationale and the concept of public ownership, the Court asserted two characteristics that it claimed set broadcasting apart from other media: broadcasting is "uniquely accessible to children,"239 and has a "uniquely pervasive presence." 240

The shift away from the public trust model and toward a private market model in First Amendment jurisprudence continued in FCC v. League of Women Voters. ${ }^{241}$ In League of Women Voters, the Supreme Court held unconstitutional Section 399 of the Public Broadcasting Act of $1967,{ }^{242}$ which forbade any "noncommercial educational broadcasting station which receives a grant from the Public Broadcasting Corporation" to "engage in editorializing."243 The Court used the rlretoric of the public trust mod$\mathrm{el}^{244}$ but noted that the "prevailing rationale for broadcast regulation"-scarcity of the electroniagnetic spectrum-liad been criticized. ${ }^{245}$ Although the Court declined to reconsider its approach absent some signal from Congress or the FCC, it did not rely on the relative priority of the public's First Amendment rights as it had in Red Lion. Instead, the Court treated broadcasters as participants in a marketplace, focusing on their First Amendment rights by treating the issue as one of editorial expression. "Section 399 plainly operates to restrict the expression of editorial opinion on niatters of public importance, and, as we have repeatedly explained, communication of this kind is entitled to the most exacting degree of First Amendment protection."246 The Court balanced broadcasters' speech rights against the public's interest in receiving a "balanced presentation of information on issues of pub-

238. See supra notes $47-51$ and accompanying text.

239. Pacifica, 438 U.S. at 749.

240. Id. at 748 .

241. 468 U.S. 364 (1984).

242. Pub. L. No. 90-129, $\S 201(8), 81$ Stat. 368, 370 (1967) (codified at 47 U.S.C. § 399).

243. 468 U.S. at 366.

244. See id. at 377 ("[G]iven spectrum scarcity, those who are granted a license to broadcast must serve in a sense as fiduciaries for the public .....").

245. Id. at 376 n.11. After citing several cases in which it had relied upon the scarcity rationale to uphold government constraints upon what may be broadcast, the Court noted several criticisms of the rationale. It concluded by stating that it was unprepared to reconsider the longstanding approach without a nod from Congress or the FCC.

246. Id. at 375-76 (citations omitted). 
lic importance that otherwise might not be addressed if control ... were left entirely in the hands of those who own and operate broadcasting stations." 247

In one miportant respect the analysis in League of Women Voters turns Red Lion on its head. Whereas in Red Lion the Court had balanced vague First Amendment interests of broadcasters against specific First Amendment rights of the public, in later cases it balanced specific First Amendment rights of broadcasters against vague First Amendment interests of the public. By prioritizing broadcasters' rights, rather than the public's, the Supreine Court has followed Congress and the FCC in treating broadcasters more like participants in a market than public trustees. In doing so, it has strengthened broadcasters' rights to control content and exclude others from use of their allotted spectrum, and has legitimated the shift to the private market model.

FCC rulings also reflect this shift in First Amendment jurisprudence. The demise of the Fairness Doctrine, which had guaranteed access to broadcasting facilities for issues of public importance and which had been upheld in Red Lion, ${ }^{248}$ caine about through FCC actions, albeit with some help from the courts. In 1985, the FCC filed its Fairness Doctrine Report. ${ }^{249}$ In it, the FCC discussed the constitutionahty of the Fairness Doctrine, but declined to decide the issue, stating only that the Fairness Doctrine had not worked as planned. ${ }^{250} \mathrm{~A}$ short time after the report was filed, the FCC was ordered by the Court of Appeals for the District of Columbia to investigate the constitutionahity of the Fairness Doctrine, ${ }^{251}$ it did so and concluded that the doctrine was unconstitutional. ${ }^{252}$ The decision to abandon the Fairness Doctrine mdicates that the public's right to hear a variety of opinions no longer holds priority over a broadcaster's right to control use of a portion of the electromagnetic spectrum. In short, the FCC's abandonment of the Fairness Doctrine had the effect of shifting First

247. Id. at 377.

248. See supra notes $92-97$ and accompanying text.

249. In re Inquiry into Section 73.1910 of the Commission's Rules and Regulations Conceming the General Faimess Doctrine Obligations of Broadcast Licensees, 102 F.C.C.2d 142 (1985).

250. Id. at $148-157,246$.

251. Meredith Corp. v. FCC, 809 F.2d 863, 874 (D.C. Cir. 1987).

252. See In re Syracuse Peace Council, Memorandum Opinion and Order, 2 F.C.C. 5043, 5047-52 (1987). 
Amendment rights from the public (where they resided during the Red Lion era) to broadcasters.

\section{CONCLUSION}

The conflict between the public trust model and the private market model is not over. Although the latter dominates current regulatory philosophy, and licensees are treated essentially as participants in a market, many cominentators and regulators still adhere at varying degrees to the public trust model. Even the current FCC Chairman, Reed Hundt, has stated that the FCC should take a more aggressive stance in requiring broadcasters to fulfill their obligations to serve the public interest. ${ }^{253} \mathrm{He}$ bases these calls for increased responsibility on the concept of public ownership of the electromagnetic spectrum, failing to recognize that public ownership is no longer the dominant paradigm of broadcast regulation.

Broadcast licensees still face public interest obligations in their roles as private market participants. ${ }^{254}$ Nonetheless, those obligations no longer define their roles, as the Communications Act of 1934 intended. ${ }^{25}$ The public's rights in the broadcast spectrum have been overtaken by those of broadcasters, and the public trust concept has been overshadowed by a vision of broadcasters as private market participants. The rise of stronger private property riglits for broadcasters has had both good and bad effects. The purpose of this Note has not been to discuss those effects; instead, it has merely described how stronger private property rights have conie to be. At a minimum, however, these rights have made First Amendment law more consistent and spectrum use more economically efficient, and have reduced some of the perverse incentives related to the allocation of a scarce resource without regard to cost.

Perhaps more significant, however, are the effects that strengthened private property rights have had and continue to

253. See Hundt, supra note 11, at 1094, 1096.

254. See Communications Act of 1934, 47 U.S.C. $\S 309$ (1994).

255. See Scripps-Howard v. FCC, 316 U.S. 4, 14 (1942) ("The purpose of the Act was to protect the public interest in communications."); see also FCC v. Pottsville Broad. Co., 309 U.S. 134, 137-38 (1940) ("[I]n granting, denying modifying or revoking licenses for the operations of stations, 'public convenience, interest, or necessity' was the touchstone for the exercise of the commission's authority."). 
have on broadcast policy. Difficulties in formulating broadcast policy are usually blamed on the political intractability of broadcasters. Those who blame broadcasters in this way fail to see a deeper problein-that political intractability is the result of broadcasters' enlarged private property rights in the electromagnetic spectrum. The stronger the broadcasters' long-term or potential long-term interests in the electromagnetic spectrum become, the more this political intractability will grow. It is irresponsible of the FCC and Congress to blame only broadcasters for the rise of private interests in broadcast regulation. After all, the FCC and Congress, albeit with soine prodding, have been the agents of the change. 